\title{
Perception and Expectation of Elective Japanese Language Learners in Malaysian Higher Education Institution: A Case Study
}

\author{
Muhammad Alif Redzuan Abdullah ${ }^{1, *} \&$ Sanimah Hussin ${ }^{2}$ \\ ${ }^{1}$ Faculty of Modern Languages \& Communication, University Putra Malaysia, 43400 UPM \\ Serdang, Selangor, Malaysia \\ ${ }^{2}$ Center for Advancement and Language Competence, University Putra Malaysia, 43400 \\ UPM Serdang, Selangor, Malaysia \\ *Corresponding author: Faculty of Modern Languages \& Communication, University Putra \\ Malaysia, 43400 UPM Serdang, Selangor, Malaysia. E-mail: muhammadalif@upm.edu.my
}

Received: July 26, 2021 Accepted: September 6, 2021 Published: September 24, 2021

doi:10.5296/ije.v13i3.18884 URL: https://doi.org/10.5296/ije.v13i3.18884

\begin{abstract}
Japanese language course registered as either compulsory elective or free elective foreign language course at University Putra Malaysia (UPM). The Japanese language is the most popular among 11 foreign language courses offered for foreign language students who wish to take global languages proficiency courses. However, their achievements in the course are inadequate as most of them are incompetent in communication skills upon completion of the course. Therefore, this article aims to identify the perception of Japanese language students in UPM to enhance their understanding of the issue. This quantitative research applies questionnaires and random purposive sampling techniques as instruments for collecting data. The sampling consists of 84 students who had enrolled in Basic Japanese level 1 course. The findings show there are significant factors attribute to students' preference for learning the Basic Japanese language. The result of the study also indicated the Kana writing and numbers are easier to acquire compared to vocabulary, sentences, grammar, and particles in the Basic Japanese 1 course. The study also revealed that mastering vocabulary plays a vital role in speaking, reading, and writing well in the Japanese language. Therefore, this study suggests that the instructor should include more engaging activities, teaching aids, and tools in the classroom to make the teaching and learning process more conducive and friendly for the students to excel in this course.
\end{abstract}

Keywords: Japanese language, perceptions of students, expectations of students, learner's belief, popular foreign language 


\section{Introduction}

More Malaysian students draw their attention to learn the Japanese language as a third language in the university due to Japan being one of the world's leading industrial powers and known for its people's strong work ethic. In addition, the Look East Policy introduced by Tun Mahathir Mohamed in 1982 had also bonded the relationship between Malaysia and Japan stronger than ever in terms of business, culture, research, education, and people-to-people exchange. Consequently, there is a strong local demand for Malaysians proficient in the Japanese language to work at Japanese companies and the Tourism sector. Japanese language is the official language of Japan and is spoken by 130 million speakers worldwide. According to a survey conducted by Japan Foundation in 2018, approximately 3.85 million people studied Japanese at a record 18,604 institutions in 137 countries (Japan Times, 2019). The number of Japanese language learners in ASEAN countries had exceeded more than 1 million. Meanwhile, the developments of Japanese language education in Malaysia have been encouraging on secondary education and higher education level. The latest survey published in the 2017 Japan Foundation Report stated that the number of Japanese language learners in Malaysia amounted to 33,224 students, with 430 teachers and 176 institutions offering Japanese language education.

The Japanese language is one of the six most popular foreign languages offered as global languages proficiency course in Universiti Putra Malaysia (UPM). UPM students in most bachelor programs require to pursue at least one level of the Global language proficiency course in line with The Malaysian Education Blueprint 2015-2025-Higher Education (MEB). Language proficiency is stressing as one of the six primary attributes found in MEB. The language proficiency attribute emphasizes students' proficiency in Bahasa Malaysia and English, as well as an emphasis on the learning of a foreign language awareness of learning the Japanese language, is due to impressive achievements in the economy, innovation, technology sector by Japan as one of the wealthiest countries in the world. In addition, it will be an advantage in career and traveling as same as understanding popular cultures and entertainment.

Japanese language courses were one of the most popular foreign language courses since introduced in UPM. This phenomenon can be traced back to manual Japanese language course registration about 20 years ago. The Japanese lecturers agreed that some of the students came as early as 4 am to queue for manual registration that opens at 9 am in the faculty before online registration was introduced in 2002 by the university academic division (Abdullah, 2005). Hussin's (2006) study stated that similar situations have persisted even after online registration was introduced in 2002 to students due to more access to their course registration. This scenario continues to the present day. The students were required to register for two weeks for the Japanese courses online by the academic division. Unfortunately, the Japanese courses quota was full even after being offered only a few hours on the registration day. Although the Japanese courses quota is closed, the students try submitting several manual appeals applications to open more places for the Japanese language course in the last few semesters.

Beliefs such as the mastery of the Japanese language can enhance the social status of the students indicating that the UPM Japanese language course students tend to look at Japanese 
culture and society. This is because the Japanese people and nations bring a respectable and exemplary image. Positive perceptions of Japanese society and society can be linked to the concept of ethno-cultural stereotypes. The admiration of the people of Malaysia towards Japan is closely linked to economic power, modern technology, high quality products and a diligent, timely and disciplined Japanese work culture. This factor is further reinforced by popular culture such as animation, song (J-pop) and drama that has so long infiltrated and become a part of Malaysian society.

\section{Literature Review}

Although Japanese language is popular among UPM students because of the added value in the job market, travelling and popular culture; but what is the students' perception of learning Japanese language after completing Basic Japanese level 1 course is really the questions that should be figured out. Consequently, many of the students cannot communicate well in Japanese language especially by the means of communicating using the language (Abdullah, 2014). The reality of this problem is the reason this research was undertaken. This is because the perceptions and expectations of the students are varied about the languages they are acquiring in the class. The educator who understands students' perceptions and expectations can facilitate them more effectively in reaching their goals and their needs. Moreover, successful students are comfortable using the language for communication and interaction (Ellis, 1994; Freed, 1995; Norton \& Toohey, 2001).

Engagement is an affective trait in oneself that will be the main factor influencing students to learn (Mok, 2004). Generally, university students are more likely to do only what they are engaged in whenever it comes on academic or non-academic matters. However, according to Langan \& Mahamod (2011), they stated that a person's attitude can affect performance as well individual satisfaction. This clearly indicates that a person's attitude will influence the actions taken both to improve the level of learning performance and to the satisfaction of the learning involved. Thus, it is crucial to know about student learning reports because it provides instructors with an opportunity to make necessary revisions. These changes could be sought to ensure the quality of the learning experience as well as to improve the learner's experience.

Additionally, students' satisfaction as well as their perception of learning plays a significant role in assessing the effectiveness of the educational method applied in a learning environment (Akkoyunlu \& Soylu, 2008). In this regard, understanding student satisfaction is a fundamental step that may provide insights into the enhancing student perception of learning. Therefore, it is important to examine satisfaction and perceived learning as students of many factors leading to an effective and successful learning program in higher education. Additionally, the most significant factors that encourage learners' motivation are their interests in the content and perceived relevance of the course (Burke \& Moore, 2003).

As Horwitz (1988) reported, learners' beliefs regarding language learning are founded on limited knowledge and experience, and these beliefs are likely to influence students' effectiveness of their learning. Teachers need to be attentive to, and conscious of, students' 
beliefs. Hence, this research is conducted to specify the features which dominate the students to prefer Japanese language as their foreign language course pursuing in UPM, perceptions of the students learning Japanese, expectations of the students after finishing the course and the needs of the students to improve their achievements in the Japanese course.

\section{Statement of Research Problem}

Japanese is one of the four most difficult foreign languages to learn in the world besides Mandarin, Arabic and Korean. Japanese is difficult to learn because its writing system consists of three different components, namely Hiragana, Katakana and Kanji based on the characters. Also, Japanese grammar is different from Malay or English. Japanese also has complex word conjugation. Among the difficulties in learning Japanese at UPM are limited vocabulary. It is well known that vocabulary is an essential part of oral or written language skills in learning basic Japanese language in Malaysian Higher Education Institution (Matsumoto \& Obana, 2001; Matsumoto, 2007; Matsumoto 2009; Hussin, 2006; Yamato et al, 2011; Bakari \& Kamaruddin, 2016; Hussin \& Abdullah, 2016; Abdullah, 2017). Factors contributing to the shortage of Japanese language vocabulary students at UPM include short hours of study time of only three hours week and surroundings outside classroom factors that do not allow students to speak Japanese. Due to the lack of vocabulary, students cannot form sentences to speak, hear or write well. Moreover, the lack of vocabulary ability may had contributed to the incompetent in communication skill. Hence, there is a need to study why this issue arises among UPM students learning Basic Japanese and hopefully this research will give find solutions for the problems above by understanding the perception and expectations of the students after completing the course.

\subsection{Research Questions}

There are three research questions, which are i) What are the factors which influence the respondents to choose Japanese language course? ii) What is the students' perception of the respondents on the Basic Japanese language 1 course? iii) What the expectation of the respondents on Basic Japanese language 1 course?

\section{Research Methodology}

\subsection{Research Design}

This study applied the quantitative research approaches. The main objective of the study was to understand perception and expectations among students in UPM on learning Basic Japanese language level 1 elective course. The design of this study included a survey using a questionnaire adapted from a recent study highlighted in the literature review for data collection. All quantitative data obtained through the questionnaires were analyzed using the Statistical Package for Social Sciences (SPSS) version 22. 


\subsection{The Participants}

The present study used the stratified purposive sampling method to select information-rich participants for the most effective use of limited resources (Patton, 2015). The participants comprised 84 students learning the Japanese language at the beginner level 1 as an elective subject. They were between 20 and 30 years of age and of different backgrounds about ethnicity, faculty, country, education, and economy. All the 84 participants involved were at the beginner level 1 of Japanese language in a public university in Malaysia. Being at the beginner level, participants need to immerse themselves in a foreign language learning environment and gradually build up core vocabulary as this would allow them to meet the objective of the Japanese classroom. The participants were asked to fill in a consent form to grant the researcher the permission to use the data obtained.

\subsection{Data Collection Instrument}

The data collection instrument chosen for this study was a set of questionnaires. This research used a set of questionnaires which is divided into two parts: Part 1 and Part 2. Part 1 includes items to gather the respondents' demographic data while Part 2 consists of items required to adhere to the research objectives.

\subsection{Data Collection}

The study was conducted after fourteen weeks of the first semester 2019/2020 to assess perception and expectations among students in UPM on learning Basic Japanese language level 1 elective course. At the beginning of the briefing on answering the survey, the lecturer informed the participants that each selected participant was given a consent form to participate in the survey. A survey questionnaire was carried out to determine the participants' perception and expectations among students in UPM on learning Basic Japanese language level 1 elective course. The survey was done online using google form since the classes were online due to the closure of university face-to-face classes because of Pandemic Covid-19.

\subsection{Data analysis}

Quantitative data obtained through the questionnaires were analyzed using the Statistical Package for Social Sciences (SPSS) version 22. Descriptive analysis was used to identify the students' perception and expectations among students in UPM on learning Basic Japanese language level 1 elective course. Interpretation of the questionnaires using a Likert scale was categorized according to positive statements that serve to measure positive perception, and negative statements which serve to measure negative perception of the participants. High responses (3-4) showed a positive perception and low responses (1-2) showed a negative perception.

\section{Findings and Discussions}

\subsection{Respondents'Demographic Profile}

The analysis of data shows that majority of the enrolment of Basic Japanese level 1 elective 


\section{Al Macrothink}

subject in UPM are Chinese students (40 respondents), followed by Malay students (31 respondents), a moderate number of foreign students (10 respondents), though a smaller number of Indian students ( 2 respondents) and other Bumiputra students ( 1 respondent). The findings of this research are like the study done by Abdullah (2005) and Hussin (2006) which reveals Basic Japanese course are popular among Chinese students, followed by Malay students and others in UPM. As can be seen in Table 1, there are more female students (55 respondents) pursuing this course than male students (29 respondents) in terms of gender. This finding is like the finding in research by Isarji et al (2007). Which shows that most of the students who enroll in Japanese language course were female students.
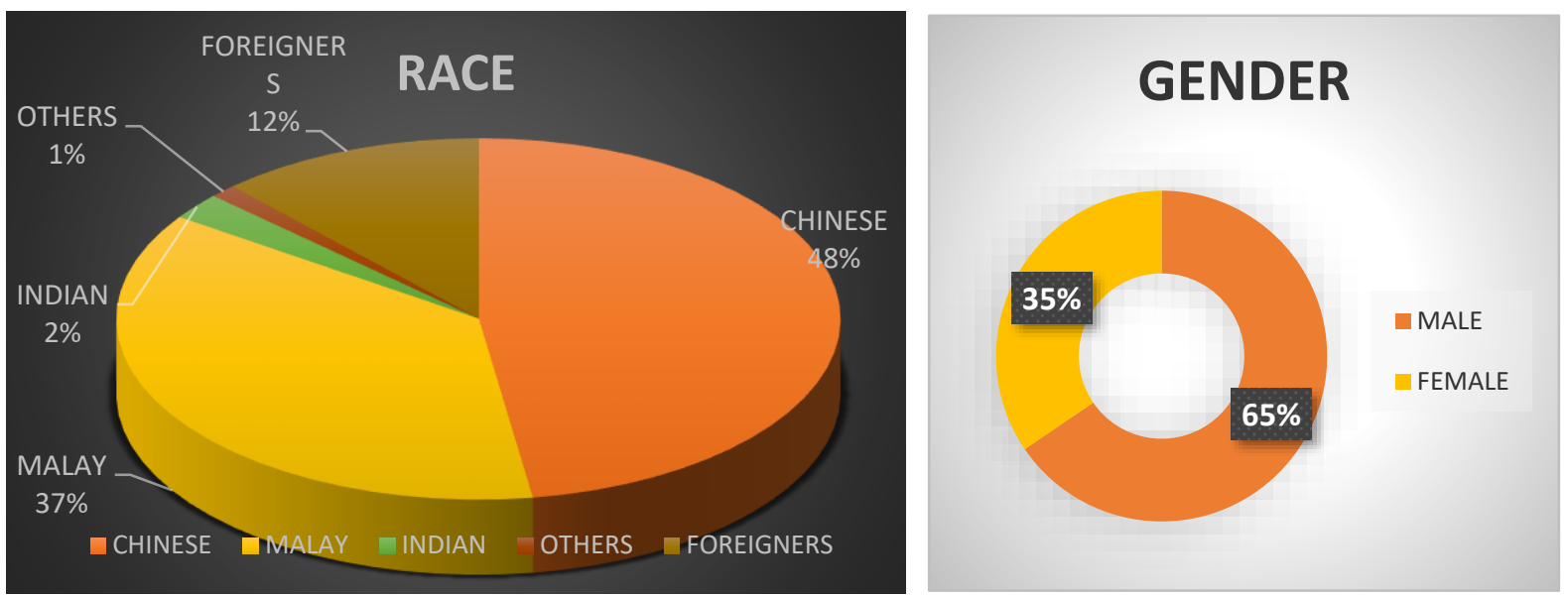

Figure 1. Demographic Profile of the Respondents

\subsection{The Preferred Foreign Language Ranked by the Respondents}

The analysis of the data in figure 1 shows that Japanese language is the most popular foreign language among the respondents who had registered for Basic Japanese language Level 1 in UPM. The second most popular foreign language is Mandarin language and followed by Arabic language. The factor behind the popularity of Japanese language among 81 respondents because Japan advancement in economic, modern technology, J-Pop culture and for leisure. The second choice of Mandarin language was only 2 respondents because of they have learned Mandarin language in the previous semester. The third choice of Arabic Language was only 1 respondent because the background as Muslim required the usage of the Arabic language in Islamic teachings and Al-Quran. The finding of this research is supported by (Kohler \& Timothy, 2007; McLauchlan, 2007; Hieda \& Maserah, 2012) which stated Japanese language is one of the most popular foreign languages studied by language learners in Malaysia. In addition, Malaysian youngsters also perceived the Japanese language as an added value in job market as well as understanding Japanese popular culture and for travelling to Japan (Abdul Aziz, 2010). 


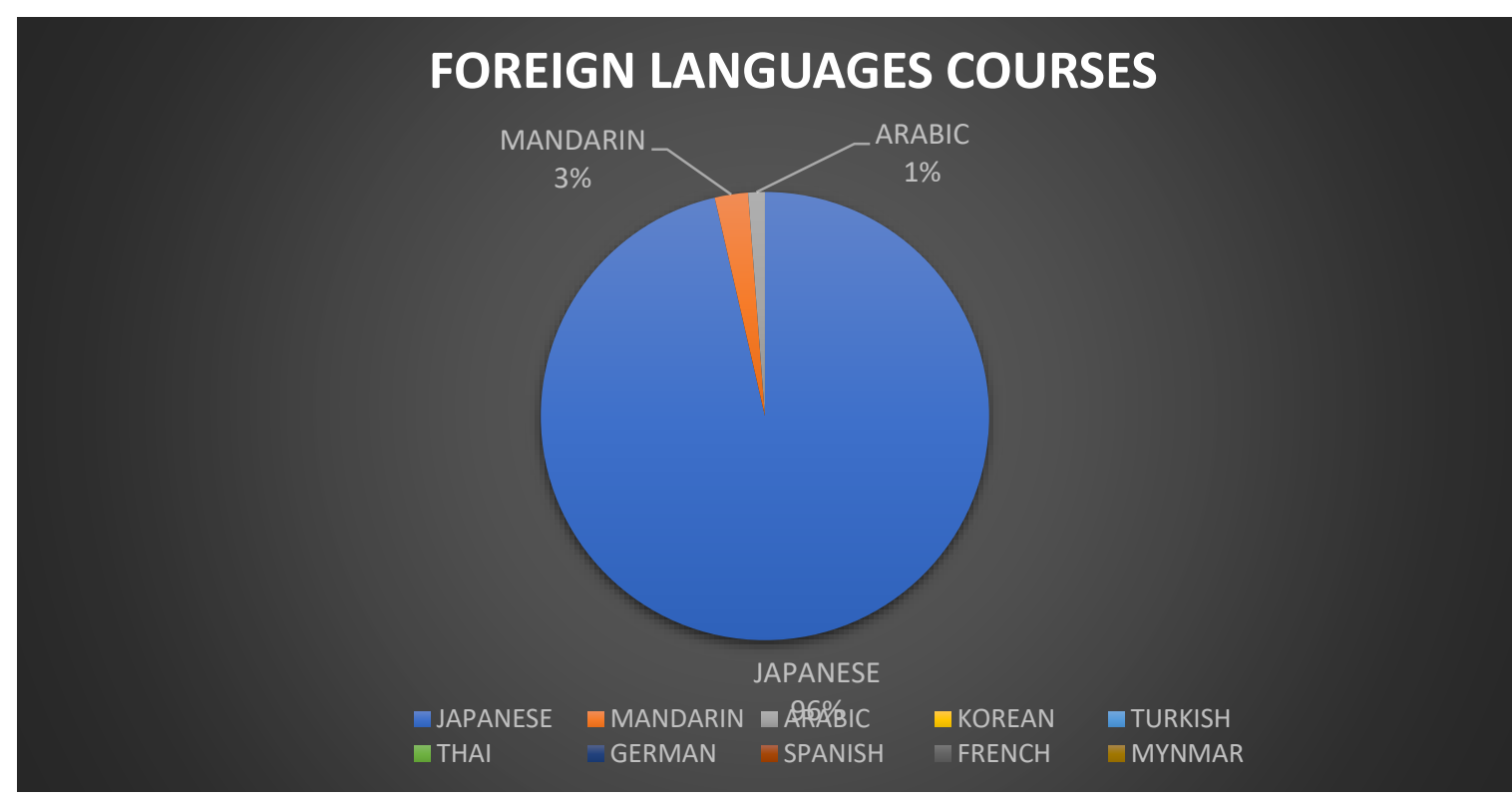

Figure 2. The Rank of Popular Foreign Languages among the Respondents

\subsection{The Factors Influencing of Choosing Japanese Language as Elective Foreign Language Course}

The analysis of the data in figure 2 shows that the selection of Japanese language among the respondents is very much influenced by the commercial and extensive value of the Japanese language. Therefore, it is very important to understand the factors which influence the students to pursue Japanese language course to know their target and goals in learning Japanese language. Mainly, the findings of this research show that most of the respondents from UPM have their own specific reasons on choosing Japanese language for their elective foreign language course. The frequencies and percentages for respondents' responses are shown in Table 1.

As shown in Table 1, the data analysis shows that there are many main factors contributed motivation among respondents to choose Japanese language as foreign language course. These factors can be divided into 11 categories as shown below:

1. Advancement in Science and Technology.

2. Added Value in Career.

3. The Characteristic of the Language.

4. Popular Culture.

5. Travelling to Japan

6. Further Education to Japan.

7. Japanese Culture.

8. Requirement to Graduate.

9. Motivated to Learn New Language.

10. No Choice

11. Similar with Mandarin Language 
Table 1. The Factors Influencing of Choosing Japanese Language as Elective Foreign Language Course

\begin{tabular}{|c|c|c|c|}
\hline Factor & Respondents' Responses & $\mathrm{N}$ & $\%$ \\
\hline $\begin{array}{l}\text { Advancement in Science } \\
\text { and Technology }\end{array}$ & Impressed with advancement of Japan since small. & 8 & 9.5 \\
\hline Added Value in Career & $\begin{array}{l}\text { Plan to work in Japan } \\
\text { Help me in my upcoming career. } \\
\text { A Plus factor when I want to find job. } \\
\text { Work in Japanese company } \\
\text { Interest in Japanese. }\end{array}$ & 8 & 9.5 \\
\hline $\begin{array}{l}\text { The Characteristic of the } \\
\text { Language }\end{array}$ & $\begin{array}{l}\text { Easy to learn compared to other foreign language. } \\
\text { Has Basic in Japanese } \\
\text { Learned before } \\
\text { The language is interesting } \\
\text { I love Japanese language } \\
\text { Learning Japanese is fun. }\end{array}$ & 8 & 9.5 \\
\hline Popular Culture & $\begin{array}{l}\text { Love Anime } \\
\text { Motivation from watching anime } \\
\text { Understand watching anime } \\
\text { Understand the caption in Japanese movie } \\
\text { Enjoy Japanese Pop Culture }\end{array}$ & 20 & 23.8 \\
\hline Travelling to Japan & $\begin{array}{l}\text { Easy to communicate with Japanese } \\
\text { Use for leisure } \\
\text { Easy to travel with command of language. } \\
\text { Visit Japan in future. } \\
\text { Japanese can't speak English. } \\
\text { Like Japan }\end{array}$ & 10 & 11.9 \\
\hline Further Education to Japan & $\begin{array}{l}\text { Doing Master } \\
\text { Plan to study in Japan }\end{array}$ & 2 & 2.4 \\
\hline Japanese Culture & $\begin{array}{l}\text { Explore Japanese culture } \\
\text { Learn the culture through the language } \\
\text { Like Japanese culture } \\
\text { To know culture from the language } \\
\text { Prefer and interested }\end{array}$ & 15 & 17.8 \\
\hline Requirement to Graduate & $\begin{array}{l}\text { Requirement of the University. } \\
\text { No choice }\end{array}$ & 3 & 3.6 \\
\hline $\begin{array}{l}\text { Motivated to Learn New } \\
\text { Language }\end{array}$ & $\begin{array}{l}\text { Learn new language } \\
\text { Willingness to learn new language } \\
\text { Interest in new language } \\
\text { Applicable in daily life } \\
\text { Useful in future }\end{array}$ & 6 & 7.2 \\
\hline No Choice & Must register & 2 & 2.4 \\
\hline Similar with Mandarin & Some similarity in writing & 2 & 2.4 \\
\hline Total & & 84 & 100 \\
\hline
\end{tabular}




\section{I Macrothink}

More than 1/5 of the 84 respondents have chosen Japanese language because of Japanese popular culture. This factor is further reinforced by popular culture such as animation, song (J-pop) and drama that has so long infiltrated and become a part of Malaysian society. The findings are consistent and supported by other researcher findings on Japanese popular culture among Malaysian Higher Education Institution on learning Japanese language (Yamato et al, 2011; Yamato 2012; Hang \& Ling, 2017). The second prominent factor is understanding Japanese culture which contributed almost $1 / 5$ of the 84 respondents. The third prominent factor is traveling to Japan which contributed more than 1/10 of the 84 respondents. These three findings are like the research done by Abdul Aziz (2010) that stated Malaysian youngsters viewed the Japanese language to understand Japanese popular culture and for travelling to Japan.

Less than 1/10 of the 84 respondents perceived Japanese language as key access to Science and Technology, added value in career, the uniqueness of the language and motivated to learn new language. This is due to the change of the opinion of the younger generation of Malaysian who are keener to use foreign language for extrinsic motivation rather than intrinsic motivation. This stated by findings of (Hieda \& Maserah, 2014) that more youngsters are viewing Japanese language for entertainment such as watching J-Pop drama, animation, and song; playing video games and travelling to Japan compared to previous generation who aimed to use Japanese language to works in Japanese company and further education to Japan. In conclusion, the student's interest in learning the Japanese language is more for the purpose of enjoyment as they can watch movies, listen to songs, and travelling purposes rather than for career, pursuing education in Japan and other economic purposes.

\subsection{The Perception of the Respondents on Basic Japanese Language 1 Course}

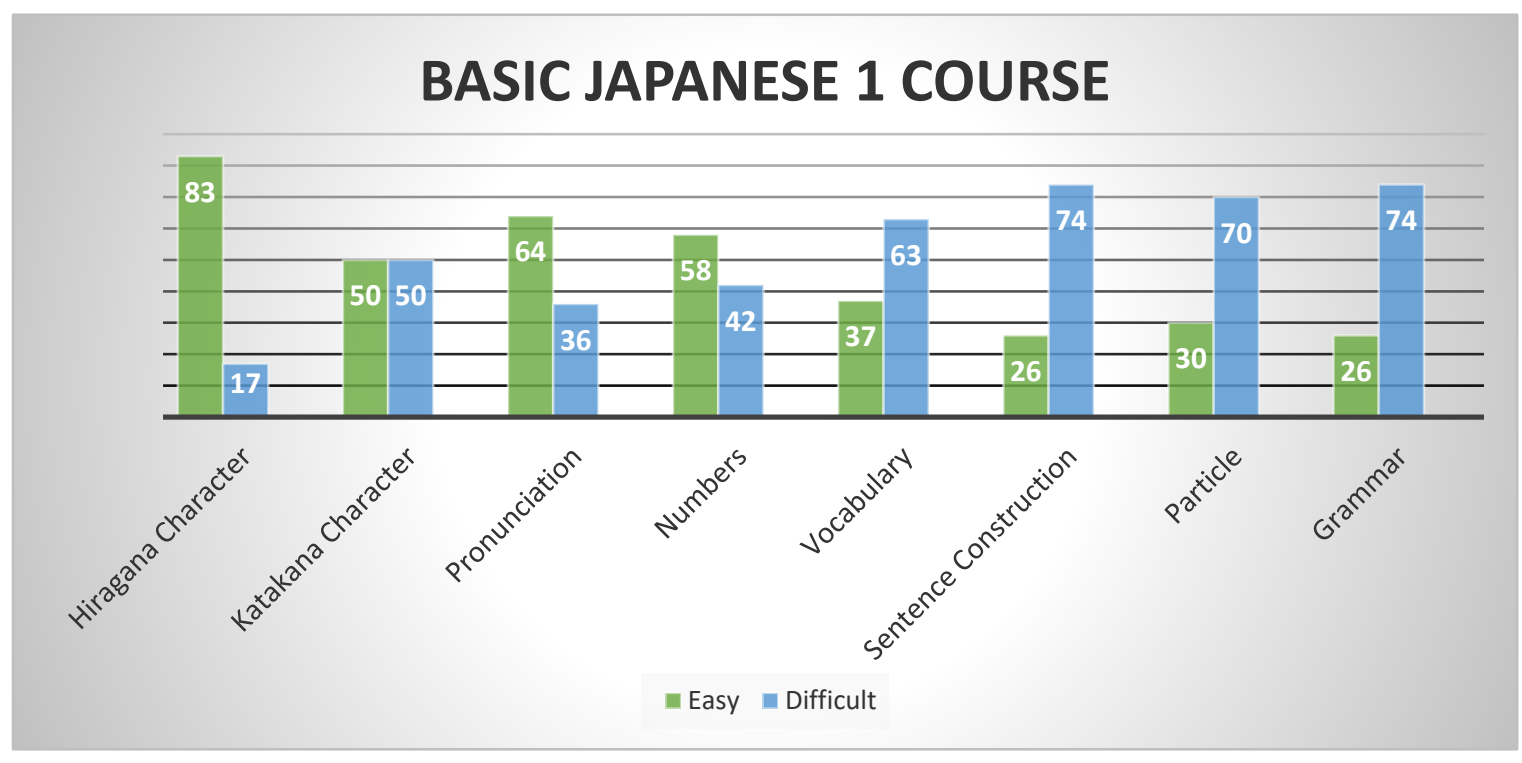

Figure 3. The Perception of the Respondents about the Syllabus of the Japanese Language Course 


\section{MlMacrothink}

International Journal of Education

ISSN 1948-5476

2021, Vol. 13, No. 3

The findings in figure 3 shows that majority of the respondents $(83 \%)$ view the learning of Hiragana character is the easiest task compared to learning of katakana character $(50 \%)$. The Japanese writing system is divided into three categories, Hiragana, Katakana and Kanji. Only Hiragana and Katakana is being introduced to UPM students (Hussin \& Abdullah, 2018; Abdullah \& Hussin, 2019). Hiragana and katakana work as the alphabet in Japanese and each represents a sound (Banno et al, 2011). Hiragana characters are introduced earlier than katakana character in UPM. Students are more familiar with Hiragana character because most words in daily use are Hiragana or kanji. The reason why katakana recognition is more difficult because learners confuse its figures and break the rules of adaptation of foreign words to the Japanese phonetic system.

Though, the $64 \%$ from the 84 respondents think Japanese pronunciation is easy task but it is based on reading words and simple sentences given in the textbook. The researcher had made some observation on the oral activities given in class, the respondents often had difficulty in uttering certain words or simple sentences fluency or accurately. Therefore, the respondents should spend more times and effort outside the classroom to improve their speaking skills. Besides that, respondents can improve their speaking skills by practicing Japanese language through watching animation, drama plays, singing and oral-audio activities (Hang \& Ling, 2017; Abdullah \& Hussin, 2019). These kinds of activities can trigger students' instinct to use more Japanese language as communication tools beside the activities in the formal classroom.

More than $60 \%$ of the 84 respondents agreed that vocabulary is most difficult part in learning Basic Japanese language 1 course in UPM. Factors contributing to the shortage of Japanese language vocabulary students at UPM include short hours of study time of only three hours week and surroundings outside classroom factors that do not allow students to speak Japanese. Due to the factor for not practicing the vocabulary outside formal classrooms, the respondents intend to forget the vocabulary learned in the classroom. When the respondents had lack of vocabulary, they cannot form correct sentences to speak, hear and write well. This in line with the findings of this research that more than $70 \%$ from 84 students agreed that sentences, grammar, and particle is the most difficult part in Basic Japanese language 1 course in UPM.

Japanese language can be break down into two basic components either in spoken or written form which are vocabulary and grammar. Vocabulary is meaning aspect units of the language and the grammar provides the rules and structures to assemble these units. In many contexts of daily life, messages can be conveyed if the grammar aspect is neglected but nothing can be conveyed without no vocabulary. This is supported by several scholars such as Wilkins (1972), Arnaud \& Sauvignon (1997), Meara (1980) and Brown (1993) that insufficient vocabulary knowledge has been found to be one of the major factors that hinder oral communication in the language classroom. In addition, there are researcher such as Nation (1990), Thornbury (2002) and Barcroft (2003) have argued that the development of vocabulary benefits the use of the target language and the lack of it may result in poor communication.

In conclusion, referring to Wilkins' words (1972) which say that "While without grammar very little can be conveyed, without vocabulary nothing can be conveyed", the mastery of 
vocabulary is very essential among UPM students to be competent in communication skills in Japanese language. This issue should be taken seriously because the findings came from the voice of respondents taking Basic Japanese level 1. As a result, more vocabulary-based activities and practices should be designed and created by Japanese language instructor to enhance and engagement vocabulary learning skill among UPM students. Hopefully, this will make students more interested and keener to use the vocabulary they acquired in the formal classroom to their daily use and improved their communication skills in Japanese language.

\subsection{The Expectations of the Respondents on Basic Japanese 1 Course}

The expectations of the respondents on Basic Japanese language 1 course were divided into three phases:

i) Before the registration of the course.

ii) During the course.

iii) After completing the course.

The expectation of the students is very important to plan, design and execute the course syllabus so that it tailored the needs of the respondents as they complete the course registered. Thus, it is crucial to know about student learning reports because it provides instructors with an opportunity to make necessary revisions. These changes could be sought to ensure the quality of the learning experience as well as to improve the learner's experience.

The analysis of the data in table 2 shows that most of the respondents had a positive motivation in choosing Basic Japanese language 1 based on their responses before the registration of the course. The responses of the respondents are very much influenced by characteristic of learning language such as gain knowledge, passionate, fun and enjoyable, challenging and interesting. Some of the respondents also had express their anxiety about the difficulty such as failure and complicating writing system. Overall, the respondents still hope for the best in learning the Basic Japanese language 1 course to pursue their ambition and interest.

The respondents had given mix responses in their opinion while pursuing the Basic Japanese language 1 course for 14 weeks. Many of them had expressed the course was interesting, enjoyable, and fun because the techniques used by the instructor was effective and engaged their learning process. Although there were some respondents had difficulty in the course because of confusion in grammar, needs a lot of practice to excel, getting difficult as course progress, had a lot of things to memorize and hard to pronounce Japanese words. Moreover, the respondents would not give up because they want to excel in the course and able to fulfil the credit requirement.

The findings also shows that the respondents had achieved they're some of their expectation in the course. Many of them can use the basic Japanese language to speak, read and write after completing this course. They would like to recommend this course to their friend and use the command of the basic Japanese language to travel to Japan. They also had expressed their satisfaction on the course and hope to purse Basic Japanese language 2 course in the next semester. Although a few of the respondents had stated the difficulty and challenging 
side of learning Basic Japanese 1 but they would like to learn in slow pace to gain more knowledge in the language.

Table 2. The Expectation of the Respondents on Basic Japanese Language 1 Course

\begin{tabular}{|c|c|c|}
\hline Before & During & After \\
\hline Excited & Fun Learning & Good experience \\
\hline Easy & Many Things to learn & Enjoyed learning \\
\hline Difficult & Difficult & Difficult \\
\hline Speak and Read Japanese & Able to read Japanese & Can communicate \\
\hline Understand Japanese & Understand a little Basic Japanese & Can use it after this semester \\
\hline Recognize Kana & Recognize Kana & Recommend to friend \\
\hline $\begin{array}{l}\text { Read Basic Hiragana and } \\
\text { Katakana Subtitles }\end{array}$ & Though to memorize and though. & $\begin{array}{l}\text { Able to speak, write and read } \\
\text { basic Japanese }\end{array}$ \\
\hline Get $\mathrm{A}$ for this course & Still learning to speak fluently & Other's friend interested \\
\hline Scared failed & Easier then learning Mandarin & Recognize Kana \\
\hline Interested & $\begin{array}{l}\text { Hard to pronounce Japanese } \\
\text { words }\end{array}$ & $\begin{array}{l}\text { More difficult than expected } \\
\text { earlier }\end{array}$ \\
\hline Try learning new language & Study hard and get good grades & Travel to Japan \\
\hline Fun Learning & Learning method is fun & Learning method fun \\
\hline Master Basic Grammar & $\begin{array}{l}\text { Memorize all the grammar and } \\
\text { vocabulary }\end{array}$ & $\begin{array}{l}\text { Knowledge on Basic Japanese } \\
\text { Grammar }\end{array}$ \\
\hline Passionate & A bit hard than expectation & Happy and satisfied \\
\hline Fluent & Useful and relaxing & Can learn in slow pace \\
\hline Complicated Writing System & Need a lot of exercise and practise & $\begin{array}{l}\text { Built confidence to speak basic } \\
\text { Japanese }\end{array}$ \\
\hline Challenge & Challenging & Challenging \\
\hline Gain Knowledge & Knowledge on Basic Japanese. & Gain information about culture \\
\hline Watch anime & $\begin{array}{l}\text { Getting Interesting as course goes } \\
\text { on. }\end{array}$ & $\begin{array}{l}\text { Focus to do better in the } \\
\text { language }\end{array}$ \\
\hline \multirow[t]{6}{*}{ Speak Basic Japanese } & It is hard but I won't give up & Continue to basic Japanese 2 \\
\hline & Confused & $\begin{array}{l}\text { Happy with level of } \\
\text { understanding }\end{array}$ \\
\hline & To fulfil credit Requirement & \\
\hline & Moderate difficult & \\
\hline & $\begin{array}{l}\text { Fully understand what had been } \\
\text { learn }\end{array}$ & \\
\hline & Still learning new things & \\
\hline
\end{tabular}

To sum up, the student's expectation was more positive than negative in the three phase of learning Japanese language. It is hope that more interesting activities, teaching aids and tools can be brought in the classroom to make the teaching and learning process more conducive 
and friendly to the students to excel in Basic Japanese language 1 course in UPM.

\section{Conclusion}

The findings of the data analysis clearly shows that the respondents' preference over Japanese language course is based on the advantages and added values the language possess, which is beneficial and profitable for their present and future. The main factors are more focused on their personal interest because Malaysian youngsters viewed the Japanese language to understand Japanese popular culture, knowing the Japanese culture and for travelling to Japan. The respondents' responses on the course syllabus of Basic Japanese Level 1 course revealed that the easiest part is more focused on Kana writing and numbers; but most of the students agreed vocabulary play a vital role in speaking, reading, and writing well in Japanese language. Additionally, they also agreed that although the difficulty and challenging side of learning Basic Japanese 1, but they would like to learn in slow pace and put more effort to gain more knowledge in the language. As a conclusion, this research suggests that more focus should be given on vocabulary learning by emphasizing on individual, peer and group activities in the class and outside class. There should be more interesting communication activities, teaching aids and tools to engaged and interact students to excel in spoken skill in Basic Japanese language 1 course in UPM.

\section{References}

Abdullah, M. A. R. (2005). Attitudes of Chinese Students towards Learning Japanese in Universiti Putra Malaysia (Unpublished Master theses). Universiti Malaya, Kuala Lumpur.

Abdullah, M. A. R. (2014). Oral Communication Strategy in Japanese Language among Malay Students in Malaysia. (Unpublished Doctoral dissertation). Universiti Putra Malaysia, Serdang.

Abdullah, M. A. R., \& Hussin, S. (2017). Oral Communication Strategy in Japanese Language among Malay Students in Malaysia. Jurnal Kemanusiaan, 15(1-S), 1-15.

Abdullah, M. A. R., \& Hussin, S. (2019). The Impact of Animated Karaoke on Vocabulary Acquisition among Japanese Language Learners in Malaysian Universities. Indonesian Journal of EFL and Linguistic, 4(1), 1-14. https://doi.org/10.21462/ijefl. v4i1.84

Abdul Azizi, S. (2010). Japanese language courses: a surging factor into the future: the foundation of Japanese studies in Malaysia. Retrieved April 5, 2020, from http://www.ritsumei.ac.jp/acd/re/k-rsc/lcs/kiyou/pdf_21-3/RitsIILCS_21.3pp75-81AZIZ. pdf

Akkoyunlu, B., \& Soylu, M. Y. (2008). A Study of Student's Perceptions in a Blended Learning Environment Based on Different Learning Styles. Journal of Educational Technology \& Society, 11(1), 183-193.https://doi.org/10.1016/j.iheduc.2007.12.006 
Al- Lawati, N. (2002). Wash-back-effect of secondary certificate English examination on teaching and learning process (Unpublished Master Thesis). ELT Curriculum and Methodology, College of Education.Sultan Qaboos University.

Arnaud, P., \& Savignon, S. (1997). Rare words, complex lexical units, and theadvanced learner. In: Coady, J., Huckin, T. (Eds.), Second language vocabulary acquisition: A rationale for pedagogy, 157-173. Cambridge: Cambridge University Press. https://doi.org/10.1017/CBO9781139524643.012

Barcroft, J. (2012). Input-based Incremental Vocabulary Instruction. Ohio: TESOL International Association Press.

Bakari, A. M., \& Kamaruddin, R. (2016). Faktor ekstralinguistik: motivasi dalam pembelajaran Bahasa kedua dalam kalangan pelajar asing di 5 universiti di Malaysia. Jurnal Antarabangsa Alam dan Tamadun Melayu (Iman), 4(2), 83-92. [In Malay]

Brown, C. (1993). Factors affecting the acquisition of vocabulary: Frequency and saliency of words. In T. Huckin \& M. Haynes \& J. Coady (Eds.), Second language reading and vocabulary learning.

Norwood, N. J., Burke, L. A., \& Moore, J. E. (2003). A perennial dilemma in OB education: Engaging the traditional student. Academy of Management Learning \& Education, 2(1), 37-52. https://doi.org/10.5465/amle.2003.9324016

Ellis, R. (1994). The Study of Second Language Acquisition. Oxford: Oxford University Press.

Freed, B. (1995). Second language acquisition in a study abroad context. Amsterdam: John Benjamins. https://doi.org/10.1075/sibil.9

Han, C. Y., \& Ling, W. N. (2017). The Use of Anime in Teaching Japanese as a Foreign Language. Malaysian Online Journal of Educational Technology, 5(2), 68-78. https://doi.org/10.17509/ijal.v7i1.6862

Hieda, N., \& Maserah, S. (2014). Sikap mahasiswa UKM terhadap bahasa Jepun: satu kajian kes. GEMA Online Journal of Language Studies, 14(1). [In Malay] https://doi.org/10.17576/GEMA-2014-1401-09

Horwitz, E. K. (1988). The Beliefs about Language Learning of Beginning University Foreign Language Students. Modern Language Journal, 72, 283-294. https://doi.org/10.1111/j.1540-4781.1988.tb04190.x

Hussin, S. (2006). Oral Communication Strategy among Japanese Language Students in Universiti Putra Malaysia (Unpublished Master theses). Universiti Malaya, Kuala Lumpur.

Hussin, S., \& Abdullah, M. A. R. (2016). The Error Analysis on the Use of Adjective or Keiyoushi in Japanese Language Composition: A Case Study of Malay Students at Universiti Putra Malaysia (UPM). Jurnal Sultan Alauddin Sulaiman Shah, 3(2), 180-194. 
Isarji, S., \& Ainol, Z. (2007). Gender Differences and Motivation to use English among Public University students in Malaysia. Paper presented at the Malaysia International Conference on Languages, Literatures, and Cultures (MICOLLAC). Subang, Malaysia, 22-24 May, 2007.

Japan Times. (2019, October 10). Numbers of Japanese Language Institutions Soars in Asia, Survey finds. Japan Times. Retrieved 1 March, 2020 from https://www.japantimes.co.jp/news/2019/10/10/national/japanese-language-schools-soar ing-asia/

Kohler, M., Curnow \& Timothy, J. (2007). Languages are important - but that's not why I am studying one [online]. Babel, 42(2), 20-24.

Langan, J. A. P., \& Mahamod, Z. (2011). Sikap dan Motivasi Murid Iban dalam Mempelajari Bahasa Melayu sebagai Bahasa Kedua. Jurnal Pendidikan Bahasa Melayu, Universiti Kebangsaan Malaysia, Kuala Lumpur. [In Malay]

Leong, L. M., \& Ahmadi, S. M. (2017). An analysis of factors influencing learner's English-speaking skill. International Journal of Research in English Education, 2(1), 1-34. Doi: 10.18869/acadpub.ijree.2.1.34

Matsumoto, H. (2007). Peak learning experiences and language learning: A study of American learners of Japanese. Language, Culture and Curriculum, 20(3), 195-208. https://doi.org/10.2167/lcc335.0

Matsumoto, M. (2009). Persistence in Japanese language study and learners' cultural/linguistic backgrounds. Retrieved from http://epublications.bond.edu.au/hss pubs/347

Matsumoto, M., \& Obana, Y. (2001). Motivational factors and persistence in learning Japanese as a foreign language. New Zealand Journal of Asian Studies, 3(1), 59-86.

McLauchlan, A. (2007). The negative L2 climate: Understanding attrition among second language students. Sasakawa Fellowship Fund for Japanese Language Education.

Meara, P. (1980). Vocabulary acquisition: A neglected aspect of language learning. Language teaching and linguistics abstracts, 13, 221-246. https://doi.org/10.1017/S0261444800008879

Mok, S. S. (2004). Psikologi Pendidikan untuk Kursus Diploma Perguruan Semester 3. Subang Jaya: Kumpulan Budiman. [In Malay]

Nation, I. (2001). Learning vocabulary in another language. Cambridge, England: Cambridge University Press. https://doi.org/10.1017/CBO9781139524759

Norton, B., \& Toohey, K. (2001). Changing perspectives on good language learners. TESOL Quarterly, 35(2), 307-322. https://doi.org/10.2307/3587650

Patton, M. Q. (2015). Qualitative research \& evaluation methods: Integrating theory and practice (4th ed.). Thousand Oaks, CA: Sage. 


\section{Macrothink}

Rabab'ah, G. (2005). Communication problems facing Arab learners of English. Journal of Language and Learning, 3(1).

Thornbury, S. (2002). How to teach vocabulary. England: Pearson Education Limited. Yamato. E, Krauss. SE, Tamam. E, Hassan. H, Osman.MN. 2011. It is part of our lifestyle: Exploring young Malaysians' experiences with Japanese popular culture. Keio Communication Review, 33, 199-223.

Yamato, E. (2012). Accumulating Japanese popular culture: Media consumption experiences of Malaysian young adults. Media Asia, 39(4). 199-208. https://doi.org/10.1080/01296612.2012.11689938

Wilkins, D. (1972). Linguistics in language teaching. London, UK: Arnold.

Zhang, S. (2009). The role of input, interaction, and output in the development of oral fluency. English Language Teaching, 2(4), 91-100. https://doi.org/10.5539/elt.v2n4p91

\section{Copyright Disclaimer}

Copyright for this article is retained by the author(s), with first publication rights granted to the journal.

This is an open-access article distributed under the terms and conditions of the Creative Commons Attribution license (http://creativecommons.org/licenses/by/3.0/). 